\title{
Floating Cage Stability With Vacuum Balance Unit
}

\author{
Henky Irawan \\ Aquaculture Department, Raja Ali Haji Maritime University, Tanjungpinang-Indonesia. \\ Maritime Technology Research Center, Raja Ali Haji Maritime University, Tanjungpinang-Indonesia \\ Corresponding Author : henkyirawan@umrah.ac.id
}

\begin{abstract}
Floating cages are the technology used for aquaculture activities. The dynamic factors of the sea will affect the floating cage, one factor is the waves. The waves cause a change in the position of the floating cage that affects the stability of the floating cage. The floating cage needs should have a balancing unit for stability. The model of a floating cage with a vacuum balancing unit is for a function to perform a stable position when exposed to sea waves. This research was executed by comparing models of the floating cages without a vacuum balancing unit with the floating cages installed with a vacuum balancing unit. The stability in each model is tested by comparing the two models of floating cages, exposed to the naturally wavy sea, for the changing in position was measured with the accelerometer data logger installed on each floating cage model. The sorted data of each data logger of the two models with identical sequences on the $\mathrm{X}$ and $\mathrm{Y}$ axes for comparison purposes. The results show that the value of the change in position is smaller for the floating cage installed in the vacuum balancing unit to perform more stability.
\end{abstract}

Keywords: Floating Cage, Aquaculture, Stability, Balance.

\section{Introduction}

Floating cages are the technology used for aquaculture activities. The dynamic factors of the sea will affect the floating cage, one factor is the waves. The waves cause a change in the position of the floating cage that affects the stability of the floating cage.

The floating cages installed with a vacuum balancing unit simple patent S00201911867 with title Keramba Apung Berpenyeimbang [1] is a floating cage prototype that developed to reduce the movement of the floating cage that exposed wavy sea. The balancing unit function is to reduce the floating cage movement when exposed to the naturally wavy sea because the aggressive movement can make fatigue also damage the structure.

The floating cage needs should have a balancing unit for stability. The model of a floating cage with a vacuum balancing unit is for a function to perform a stable position when exposed to sea waves. This research was executed by comparing models of the floating cages without a vacuum balancing unit with the floating cages installed with a vacuum balancing unit.

\section{Method}

The experiment is by comparing two models of floating that are built from 4 inch PVC pipe and 4 inch PVC joint:

a. Model A is the floating cages without a vacuum balancing unit

b. Model B is the floating cages installed with a vacuum balancing unit

The experiment is at exposed the two models to the naturally wavy sea with 3 trials. The accelerometer data logger installed on each floating cage model is placed on the front side at the right corner of the structure.

\section{Parameters:}

a. X-axis movement

b. Y-axis movement 


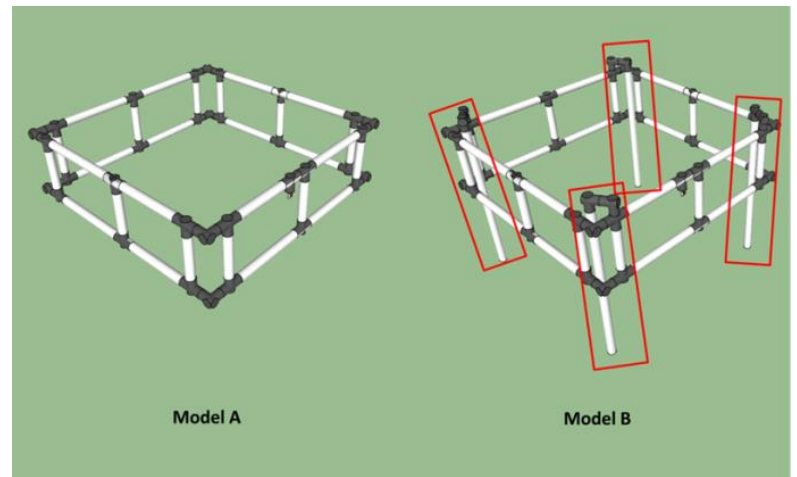

Fig 1. The schematic floating cage model A and B. The red rectangle framed is the vacuum balance unit

The seawater volume inside each vacuum balance unit is $9.63 \mathrm{~L}$, the weight of seawater (31 ppt) inside each vacuum balance unit is $9.6 \mathrm{Kg}$, and the total weight of seawater (31 ppt) in all vacuum balance units is 38.4 Kg.

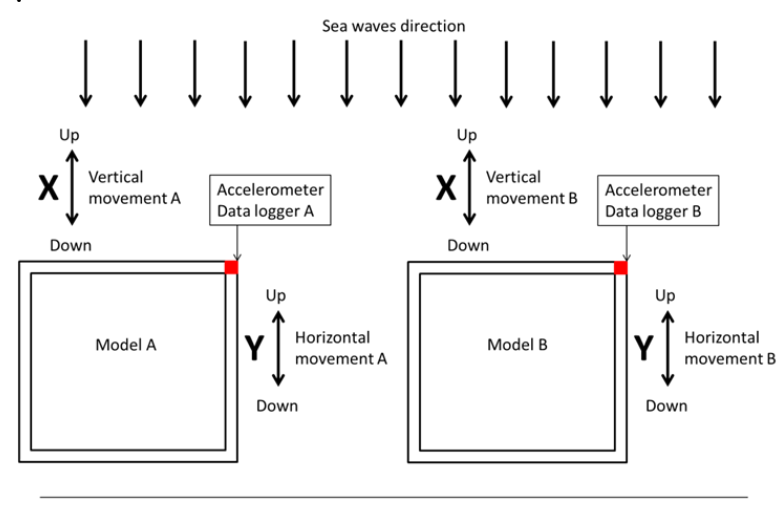

Coastal line

Fig 2. The schematic of trial in exposing the two models to the naturally wavy sea

\section{Data:}

The $\mathrm{X}$-axis and $\mathrm{Y}$-axis data are extracted from each data logger of both models and sorted with identical sequences on the $\mathrm{X}$-axis and $\mathrm{Y}$-axis. The $\mathrm{X}$-axis and $\mathrm{Y}$ axis data were transformed with square root transformation and analysis Wilcoxon signed-rank nonparametric.

\section{Result and Discussion}

\subsection{Result}

\section{The $\mathrm{X}$-axis comparison}

The results from the mean of movement value (Table 1 and 2) and comparison of models A and B in the Xaxis mean value movement (Tabel 3 ) show that there is a significant reduction in the movement in model $\mathrm{B}$. Comparison of the movement (Fig 3, 4, and 5) shows how models $\mathrm{A}$ and $\mathrm{B}$ respond.

Table 1. The X-axis movement of model $\mathrm{A}$ in each trial

\begin{tabular}{ccccc}
\hline No & Trial & Code & $\begin{array}{l}\text { Number of } \\
\text { movements }\end{array}$ & $\begin{array}{c}\text { Mean of movement } \\
\text { value } \\
\text { transformation) }\end{array}$ \\
\hline 1 & 1st & A1 & 189 & 3.386 \\
2 & 2nd & A2 & 96 & 2.971 \\
3 & 3rd & A3 & 159 & 3.137 \\
\hline
\end{tabular}

Table 2. The $\mathrm{X}$-axis movement of model $\mathrm{B}$ in each trial

\begin{tabular}{llccc}
\hline No & Trial & Code & $\begin{array}{c}\text { Number of } \\
\text { movements }\end{array}$ & $\begin{array}{c}\text { Mean of movements } \\
\text { value } \\
\text { transformation) }\end{array}$ \\
\hline 1 & 1st & B1 & 189 & 2.156 \\
2 & 2nd & B2 & 96 & 1.022 \\
3 & 3rd & B3 & 159 & 2.001 \\
\hline
\end{tabular}

Table 3. The comparison of models A and B in X-axis movement

\begin{tabular}{lllllll}
\hline No & Trial & A & B & $\begin{array}{l}\text { Redu } \\
\text { ce } \\
\text { move } \\
\text { ment } \\
\text { s }\end{array}$ & $\begin{array}{l}\text { Percenta } \\
\text { ge of } \\
\text { Reduce } \\
\text { moveme } \\
\text { nts }\end{array}$ & $\begin{array}{l}\text { Signifi } \\
\text { cant }\end{array}$ \\
& & & & 1.23 & $36.33 \%$ & $\mathrm{P}<0.001$ \\
\hline 1 & 1st & 3.386 & 2.156 & 1.949 & $65.60 \%$ & $\mathrm{P}<0.001$ \\
2 & 2nd & 2.971 & 1.022 & 1.940 & $\mathrm{P}<0.001$ \\
\hline
\end{tabular}

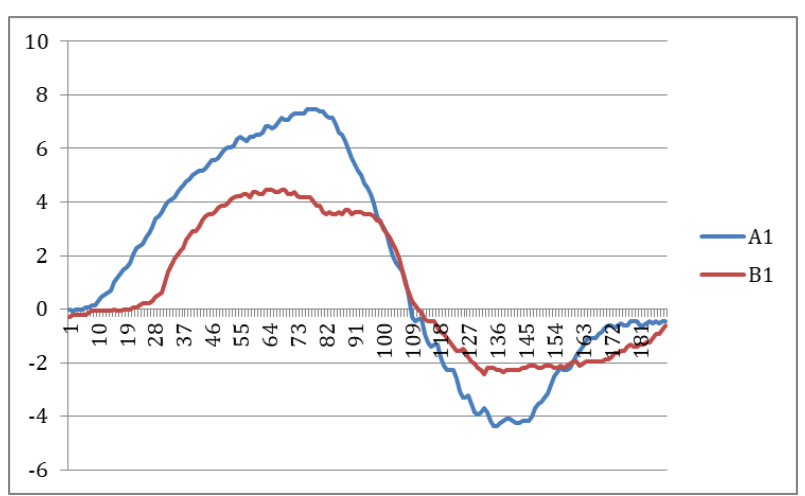

Fig 3. The comparison graph of the $\mathrm{X}$-axis sequence from models A1 and B1 at the 1st trial

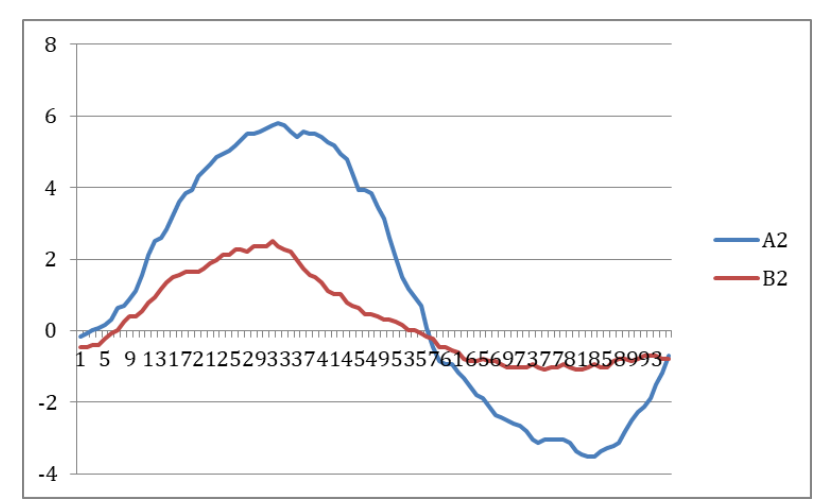

Fig 4. The comparison graph of the $\mathrm{X}$-axis sequence from models A2 and B2 at the 2nd trial 


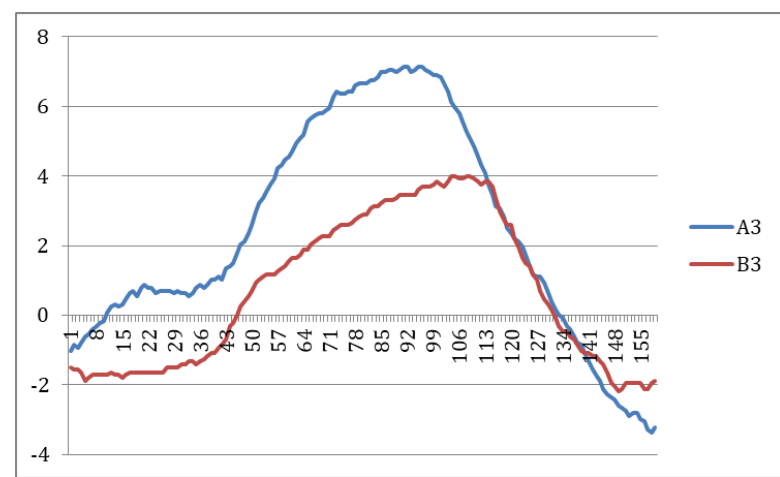

Fig 5. The comparison graph of the $\mathrm{X}$-axis sequence of models $\mathrm{A} 3$ and $\mathrm{B} 3$ at the 3 rd trial

\section{The $\mathrm{Y}$-axis comparison}

The results from the mean of movement value (Table 4 and 5) and comparison of model $\mathrm{A}$ and $\mathrm{B}$ in the $\mathrm{Y}$-axis mean value movement (Tabel 6) show that there is a significant reduction in the movement in model $\mathrm{B}$. Comparison of the movement (Fig 6, 7, and 8) shows how models $\mathrm{A}$ and $\mathrm{B}$ respond.

Table 4. The $\mathrm{Y}$-axis movement of model $\mathrm{A}$ in each trial

\begin{tabular}{llcclc}
\hline No & Trial & Code & $\begin{array}{l}\text { Number of } \\
\text { movements }\end{array}$ & $\begin{array}{l}\text { Mean of } \\
\text { movements } \\
\text { value (square } \\
\text { root } \\
\text { transformation) }\end{array}$ \\
\hline 1 & 1st & A1 & 189 & 0.089 \\
2 & 2nd & A2 & 96 & 0.088 \\
3 & 3rd & A3 & 159 & 0.092 \\
\hline
\end{tabular}

Table 5. The $\mathrm{Y}$-axis movement of model $\mathrm{B}$ in each trial

\begin{tabular}{llcclc}
\hline No & Trial & Code & $\begin{array}{l}\text { Number of } \\
\text { movements }\end{array}$ & $\begin{array}{l}\text { Mean of } \\
\text { movements } \\
\text { value (square } \\
\text { root } \\
\text { transformation) }\end{array}$ \\
\hline 1 & 1st & B1 & 189 & 0.066 \\
2 & 2nd & B2 & 96 & 0.091 \\
3 & 3rd & B3 & 159 & 0.068 \\
\hline
\end{tabular}

Table 6. The comparison of models A and B in Y-axis movement

\begin{tabular}{|c|c|c|c|c|c|c|}
\hline No & Trial & A & B & $\begin{array}{l}\text { Reduc } \\
\mathrm{e} \\
\text { move } \\
\text { ments }\end{array}$ & $\begin{array}{l}\text { Percenta } \\
\text { ge of } \\
\text { Reduce } \\
\text { moveme } \\
\text { nts }\end{array}$ & $\begin{array}{l}\text { Significa } \\
\text { nt }\end{array}$ \\
\hline 1 & $1 \mathrm{st}$ & 0.089 & 0.066 & 0.023 & $25.84 \%$ & $\mathrm{P}<0.001$ \\
\hline 2 & 2nd & 0.088 & 0.091 & -0.003 & $-3.41 \%$ & $P>0.05$ \\
\hline 3 & $3 \mathrm{rd}$ & 0.092 & 0.068 & 0.024 & $26.09 \%$ & $\mathrm{P}<0.001$ \\
\hline
\end{tabular}

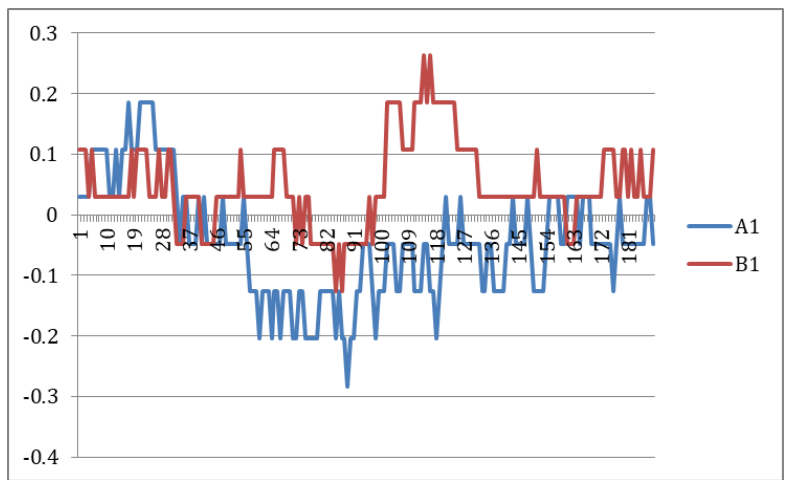

Fig 6. The comparison graph of $\mathrm{Y}$-axis sequence form models $\mathrm{A} 3$ and $\mathrm{B} 3$ at the 1 st trial

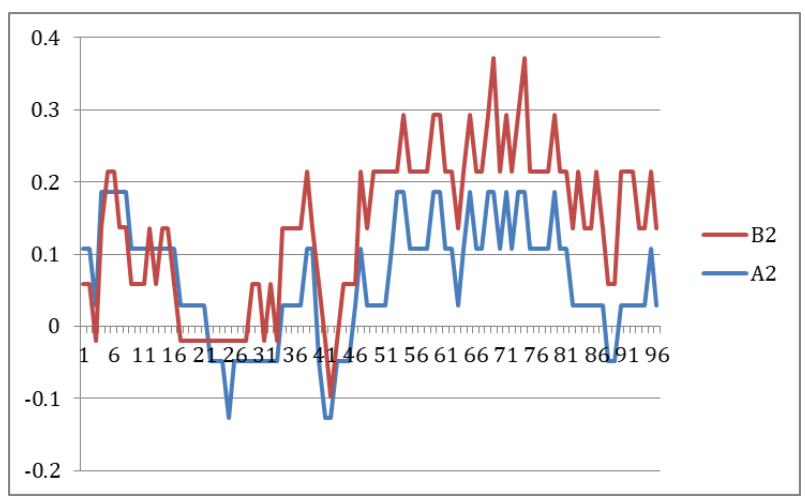

Fig 7. The comparison graph of the $\mathrm{Y}$-axis sequence from models A2 and B2 at the 2nd trial

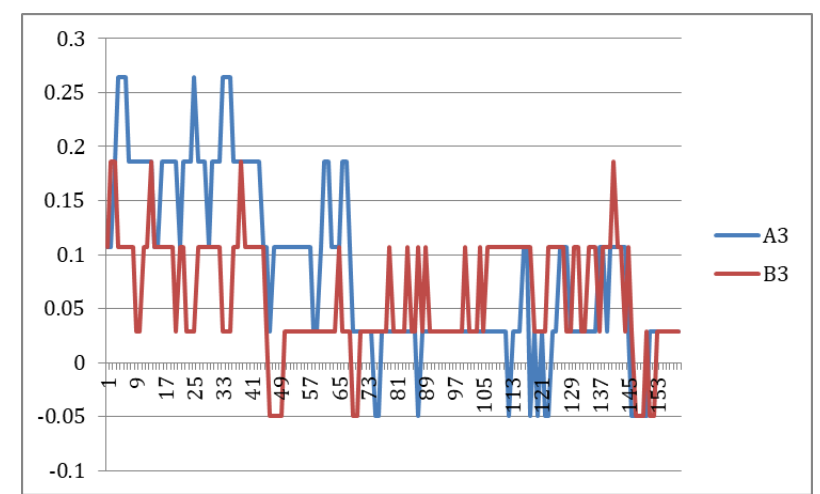

Fig 8. The comparison graph of the $\mathrm{Y}$-axis sequence of models $\mathrm{A} 3$ and $\mathrm{B} 3$ at the 3 rd trial

\subsection{Discussion}

The floating cage with a rectangular shape has the same stability as the hexagonal shape and better stability than the circular-shaped [2]. The movement of the floating cage in waves will increase with the wave height and will follow the movement of water particles [3] [4]. The floating cage deformation becomes greater as the wave height or current velocity increase [5].

The floating cage moves more significantly in the vertical direction than in the horizontal direction [6]. The floating cage fatigue will increase in typhoons and can reduce the lifetime of the floating cage [7]. The wave can cause stress to the floating cage structure [8]. The floating cage balanced dynamically when the reserve buoyancy was up and down to the vertical 
downward force component resulting from increased environmental forces [9]

\section{Conclusion}

The vacuum balancing unit can reduce the floating cage vertical movement by $36.21 \%-65.6 \%$. The vacuum balancing unit can reduce the floating cage horizontal movement by $25.84 \%-26.09 \%$. The value of the reduction in movement is smaller for the floating cage installed in the vacuum balancing unit to perform more stability.

Acknowledgments. The work was supported financially by an internal 2019 scholarship from Lembaga Penelitian, Pengabdian Masyarakat dan Penjaminan Mutu (LP3M) Universitas Maritim Raja Ali Haji.

\section{References}

[1] H. Irawan, "Keramba Apung Berpenyeimbang," S00201911867, 2019.

[2] Y. A. Wibowo and M. R. Hakim, "Dynamic Response of Circular, Hexagonal and Rectangular Shaped Floating Fish Cage in Waves," no. Senta 2018, pp. 20-26, 2020.

[3] L. Li, S. Fu, Y. Xu, J. Wang, and J. Yang, "Dynamic responses of floating fish cage in waves and current," Ocean Eng., vol. 72, pp. 297-303, 2013.

[4] X. Bai, C. Yang, and H. Luo, "Hydrodynamic performance of the floating fish cage under extreme waves," Ocean Eng., vol. 231, no. April, p. 109082, 2021.

[5] X. H. Huang et al., "Dynamic deformation of the floating collar of a net cage under the combined effect of waves and current," Aquac. Eng., vol. 83, no. 231, pp. 47-56, 2018.

[6] G. H. Dong, Y. N. Zheng, F. K. Gui, B. Teng, and Y. C. Li, "Research on the Float Collar of a Gravity Fish Cage," Eng. Appl. Comput. Fluid Mech., vol. 3, no. 3, pp. 430-444, 2009.

[7] X. D. Bai, T. J. Xu, Y. P. Zhao, G. H. Dong, and C. W. Bi, "Fatigue assessment for the floating collar of a fish cage using the deterministic method in waves," Aquac. Eng., vol. 74, pp. 131142, 2016.

[8] Y. P. Zhao, C. W. Bi, X. X. Sun, and G. H. Dong, "A prediction on structural stress and deformation of fish cage in waves using machinelearning method," Aquac. Eng., vol. 85, no. December 2018, pp. 15-21, 2019.

[9] H. Liu, X. Huang, S. Wang, Y. Hu, T. Yuan, and G. Guo, "Evaluation of the structural strength and failure for floating collar of a single-point mooring fish cage based on finite element method," Aquac. Eng., vol. 85, no. December 2018, pp. 32-48, 2019. 